\title{
Lima beans production and economic revenue as function of organic and mineral fertilization
}

\author{
Adriana U Alves'; Ademar P de Oliveira²; Anarlete U Alves³; Carina SM Dornelas ${ }^{3}$; Edna U Alves²; Edson \\ A Cardoso'; Arnaldo Nonato P de Oliveira²; Iordan da S Cruz ${ }^{2}$ \\ ${ }^{1}$ UNESP-FCAV, Dep ${ }^{\text {to }}$ Produção Vegetal, 14884-900 Jaboticabal-SP; ${ }^{2}$ UFPB-CCA, C. Postal 02, 58397-000 Areia-PB; ${ }^{3}$ UFPB, pós- \\ graduando; ademar@cca.ufpb.br
}

\begin{abstract}
Lima beans (Phaseolus lunatus L.) are alternative food and income sources for the population of Northeastern Brazil. In this region, lima beans are consumed either as green or dry grains. However, low yields have been observed, a challenge that could be overcome by adequate organic and mineral fertilization. This work intended to assess lima beans yield, cultivar Raio de Sol, as affected by doses of cattle manure in the presence and absence of mineral NPK fertilization. The experiment was carried out at the Federal University of Paraíba, Brazil, from September, 2004 to May, 2005. The experimental design was of randomized blocks, with four replications, 40-plant plots, spaces of $1.00 \times 0.50$ between and within rows, respectively. Treatments were displayed in a $6 \times 2$ factorial, corresponding to manure doses $\left(0,10,20,30,40\right.$ and $\left.50 \mathrm{t} \mathrm{ha}^{-1}\right)$ and presence and absence of NPK. Green and dry grain, and pod yields were analysed, as well as the economic revenue for pods and dry grains. To measure the economic efficiency, pods and dry grains were employed as the exchange units. Maximum pod yields (12.6 and $11.2 \mathrm{t} \mathrm{ha}^{-1}$ ) were achieved with 21.4 and $23 \mathrm{t} \mathrm{ha}^{-1}$ of manure, with and without NPK, respectively. Highest green grain yields (11.1 and $9.9 \mathrm{t} \mathrm{ha}^{-1}$ ) were obtained with 21.3 and $22.9 \mathrm{t} \mathrm{ha}^{-1}$ of manure, with and without NPK, respectively. The highest yield of dry grains (3.5 $\mathrm{t} \mathrm{ha}^{-1}$ ) was obtained with $26.6 \mathrm{t} \mathrm{ha}^{-1}$ of manure combined with NPK. In the absence of NPK, the use of cattle manure resulted in an average dry grain yield of $2.0 \mathrm{t} \mathrm{ha}^{-1}$. The maximum economic efficiency for pod production was reached with 17 and $18.6 \mathrm{t} \mathrm{ha}^{-1}$ of manure, with predicted net incomes of 2.88 and $3.36 \mathrm{t} \mathrm{ha}^{-1}$ of pods, in the presence and absence of NPK, respectively. For dry grains, the maximum economic efficiency was achieved with $23 \mathrm{t} \mathrm{ha}^{-1}$ of manure, in the presence of NPK, which produced a net revenue of $2.12 \mathrm{tha}^{-1}$ of dry grains.
\end{abstract}

Keywords: Phaseolus lunatus L., organic fertilization, mineral fertilization, yield.

\section{RESUMO}

Produção do feijão-fava e retorno econômico em função da adubação organomineral

O feijão-fava (Phaseolus lunatus L.) é uma alternativa de renda e alimento para a população do Nordeste do Brasil, que consome seus grãos maduros ou verdes. No entanto, níveis baixos de produtividade têm sido constatados, dificuldade que pode ser vencida pela utilização de fertilização orgânica e mineral. Com o objetivo de avaliar a produtividade do feijão-fava, cultivar Raio-de-Sol, em função de doses de esterco bovino, na presença e ausência de NPK, este trabalho foi realizado. O experimento foi conduzido na UFPB, em Areia, de setembro de 2004 a maio de 2005 . O delineamento experimental utilizado foi blocos casualizados, em fatorial $6 \times 2$, com os fatores doses de esterco bovino $\left(0 ; 10 ; 20 ; 30 ; 40\right.$ e $\left.50 \mathrm{t} \mathrm{ha}^{-1}\right)$ e presença e ausência de NPK, quatro repetições e parcelas de 40 plantas, espaçadas de $1,00 \times$ x 0,50 m. Foram avaliadas as produtividades de vagens e de grãos verdes e secos e o retorno econômico de vagens e grãos secos. Para cálculo da eficiência econômica, foram utilizados a própria vagem e o grão seco como relação de troca. As doses 21,4 e $23 \mathrm{t} \mathrm{ha}^{-1}$ de esterco bovino proporcionaram produtividade máxima de vagens (12,6 e 11,2 t ha-1) na presença e ausência de NPK, respectivamente, enquanto as doses 21,3 e $22,9 \mathrm{t} \mathrm{ha}^{-1}$ de esterco bovino proporcionaram produtividades máximas de grãos verdes $(11,1 \mathrm{e}$ $9,9 \mathrm{t} \mathrm{ha}^{-1}$ ) na presença e ausência de NPK, respectivamente. A dose 26,6 $\mathrm{t} \mathrm{ha}^{-1}$ de esterco bovino foi responsável pela produtividade máxima $\left(3,5 \mathrm{t} \mathrm{ha}^{-1}\right)$ de grãos secos, na presença de NPK. Na ausência de NPK, obteve-se a produtividade média de 2,0 t ha- ${ }^{-1}$, em função das doses de esterco bovino. As doses de 17,0 e 18,6 tha-1 de esterco bovino proporcionaram máximas eficiências econômicas para a produtividade de vagens, com receitas previstas de 2,88 e 3,36 t $\mathrm{ha}^{-1}$, respectivamente, na presença e na ausência de NPK. Para a produtividade de grãos secos na presença de NPK, a máxima eficiência econômica foi obtida com $23 \mathrm{t} \mathrm{ha}^{-1}$ de esterco bovino, que gerou uma receita de $2,12 \mathrm{t} \mathrm{ha}^{-1}$.

Palavras-chave: Phaseolus lunatus L., adubação orgânica, adubação mineral, rendimento.

(Recebido para publicação em 16 de outubro de 2007; aceito em 27 de maio de 2008)

L ima beans (Phaseolus lunatus L.) rank among the most popular legumes in tropical regions due to its ample adaptation and good protein production. As consequence, the species is a pragmatic option to reduce the dependence on common beans (Vieira, 1992a). It is also known as butter bean, Sieva bean, and sugar bean. Lima beans represent an alternative source of food and income for the population of Northeast Brazil. In this region, it is cultivated by small-scale farmers, who use bushing cultivars (Santos et al., 2002). In US, one of the largest world producers, lima beans are consumed processed, either as canned or frozen green grains. In Brazil, green or dry grains are cooked before consumption and the Lima beans use is relatively less important than other Phaseolus species (Vieira, 1992b).

Paraíba, one of the Brazilian States in the Northeast region, is among the top national producers of Lima beans, reaching annually $9.35 \mathrm{t}$ of dry grains. Nevertheless, yields are low (476 $\left.\mathrm{kg} \mathrm{ha}^{-1}\right)$, 
as consequence of the restricted level of technology use in the farms (Santos et al., 2002). The lack of improved cultivars (Santos et al., 2002) and the habit of sowing with no organic and mineral fertilization contribute to the low yield levels and poor economic revenues, practically turning Lima beans into a subsistence crop. Thus, only production surplus is trade, usually, in local street free markets (Frazão et al., 2004).

The benefits of organic fertilization are indisputable, but there is not much information on the amount needed to significantly improve Lima beans yield. On the other hand, the indiscriminated use of manure may increase nitrogen levels and lead to soil salinization and increase in electric conductivity, which cause plant nutritional imbalance and result in hampering crop yield (Silva et al., 2000). Lima beans grow well in sandy or medium texture soils, with $\mathrm{pH}$ preferably between 5.6 to 6.8 (Filgueira, 2000). It is a high nutrient demanding species, and may extract $135 \mathrm{~kg} \mathrm{ha}^{-1}$ of $\mathrm{K}, 91$ of $\mathrm{N}, 81$ of $\mathrm{Ca}, 30$ of $\mathrm{P}$, and 11 of Mg (Hester et al., 1951). According to Filgueira (1981), only P should be supplied in planting fertilization, unless the soil is poor in $\mathrm{K}$. In this case, both $\mathrm{K}$ and $\mathrm{N}$ should be used. Increase in Lima beans yield as consequence of mineral fertilization is largely documented (Vieira et al., 1992; Frazão et al., 2004; Oliveira et al., 2004). Increase in yield due to organic fertilization was reported in cowpea with the use of cattle manure (Oliveira et al., 2001) and in bush beans fertilized with swine manure (Araújo et al., 2001). In Lima beans, Filgueira (2000) recommends the use of organic fertilization in soils with low fertility levels.

The objective of this work was to study the variation on Lima beans yield as function of the use of mounting doses of cattle manure, in the presence and absence of mineral NPK fertilization.

\section{MATERIAL AND METHODS}

The experiment was carried out from September, 2004, to May, 2005, at the Federal University of Paraíba, in Brazil (658'12' 'S, 3542'15' W, $575 \mathrm{~m}$ above sea level). According to Köppen bioclimatic classification, the climate is As' type (Brasil, 1972), characterized as hot and humid, with fall-winter rains. The average air temperature oscillates between 23 and $24^{\circ} \mathrm{C}$, with minimum monthly variations. The soil at the experimental area is classified as typical Quartz psamment (Embrapa, 1999), with the following chemical characteristics (Embrapa, 1997): pH $\left(\mathrm{H}_{2} \mathrm{O}\right)=6.5, \mathrm{P}$ available (Mehlich 1 extractor) $=51.33 \mathrm{mg} \mathrm{dm}^{-3}, \mathrm{~K}=99.0$ $\mathrm{mg} \mathrm{dm}{ }^{-3}, \mathrm{Al}$ exchangeable $=0.0 \mathrm{cmol}_{\mathrm{c}}$ $\mathrm{dm}^{-3}, \mathrm{Ca}+\mathrm{Mg}=2.25 \mathrm{cmol} \mathrm{dm}^{-3}$, and $11.61 \mathrm{~g} \mathrm{~kg}^{-1}$ of organic matter. The cattle manure used in the experiment presented the following chemical characteristics: $\mathrm{P}=5.2 \mathrm{~g} \mathrm{~kg}^{-1}, \mathrm{~K}=4.9 \mathrm{~g}$ $\mathrm{kg}^{-1}, \mathrm{~N}=3.2 \mathrm{~g} \mathrm{~kg}^{-1}$, organic matter $=$ $112.07 \mathrm{~g} \mathrm{dm}^{-3}$, and $\mathrm{C} / \mathrm{N}$ ratio $=14 / 1$.

The experimental design was blocks at random, with four replications. Treatments were displayed in a $6 \times 2$ factorial, corresponding to six cattle manure doses $(0 ; 10 ; 20 ; 30 ; 40$ and 50 $\mathrm{t} \mathrm{ha}^{-1}$ ), with and without mineral NPK fertilization. The experimental plot, with a total area of $4 \mathrm{~m}^{2}$, had 40 plants driven by crossed sticks, with spaces of $1.00 \mathrm{x}$ $0.50 \mathrm{~m}$ between and within rows respectively. Twenty plants were used for harvesting green pods and, the remaining 20, for harvesting dry pods. The experimental area was prepared by clearing, weeding, ridging, and opening of holes, using hoes. Fertilization with the cattle manure took place fifteen days before sowing. Five seeds of cultivar Raio de Sol were manually placed in each hole. The rough-hewing was carried out 15 days after sowing, leaving two plants per hole. Mineral fertilization at planting, where appropriate, consisted of $30 \mathrm{~kg} \mathrm{ha}^{-1}$ of $\mathrm{P}_{2} \mathrm{O}_{5}$ (simple superphosphate) and $60 \mathrm{~kg} \mathrm{ha}^{-1}$ of $\mathrm{K}_{2} \mathrm{O}$ (potassium chloride). Dressing fertilization consisted of $30 \mathrm{~kg} \mathrm{ha}^{-1}$ of $\mathrm{N}$ (urea), half at 30 and half at 60 days after sowing. The amounts of simple superphosphate, potassium chloride, and urea were established according to the recommendation of the Chemistry and Soil Fertility Laboratory, Centre for Agricultural Sciences of the Federal University of Paraíba, based on the recommendation for Lima beans fertilization at the neighbor State of
Ceará (UFC, 1990). During the experiment, hand weeding and conventional sprinkling irrigation were used, obeying a three-day irrigation frequency and using a water depth of $9.0 \mathrm{~mm}$. Pest and disease control were not necessary.

Hand harvests were performed weekly from February to March, 2005. Pods and green and dry grains yield were assessed. Data were submitted to analyses of variance and regression. The significant model with the highest rank and determination coefficient was selected to represent the effects of manure doses and mineral fertilization. Analyses were performed using the software SAEG (2000).

Doses of manure that resulted in the highest economic revenues of pods and dry grains were also estimated (Raij, 1991). Green grains were not included in the economic analysis because their market has minor importance. The actual values for pods, dry grains, and manure at Areia, in October, 2005, were $\mathrm{R} \$ 0,50 \mathrm{~kg}^{-1}$ for pods, $\mathrm{R} \$ 1,50 \mathrm{~kg}^{-1}$ for dry grains, and $\mathrm{R} \$ 0,043 \mathrm{~kg}^{-1}$ for manure. It must be mentioned that these prices vary from season to season according to the supply and demand. To mitigate the effects of exchange rate fluctuation, pods and dry grains were used as monetary units, since their values are more stable than the currency (Natale et al., 1996). The equivalence rates adopted were 0,086 and 0,029 for respectively manure:pods and manure:dry grains. The most economic doses were estimated from the derivatives of the regression equations between pod and dry grain yield and doses of manure, using the relation $\mathrm{dy} /$ $\mathrm{dx}=\mathrm{a}_{1}+2 \mathrm{a}_{2} \mathrm{x}$. The most economic dose ( $x$ ') was then calculated using the equation $x^{\prime}=a_{1}-$ equivalence rate $/ 2$ ($a_{2}$ ), where $x$ ' stands for the economic dose, $a_{1}$ for the yield increment rate, and $\mathrm{a}_{2}$ for the point of maximum yield.

\section{RESULTS AND DISCUSSION}

There were significant interactions between doses of manure and presence and absence of NPK for pod and green grain yield $(\mathrm{p}<0.05)$ and significant effect of doses of manure over dry grain yield only in the presence of NPK. 
The highest pod $\left(12.6 \mathrm{t} \mathrm{ha}^{-1}\right)$ and green grain $\left(11 \mathrm{t} \mathrm{ha}^{-1}\right)$ yield estimates were reached respectively with 21.4 and $21.3 \mathrm{t} \mathrm{ha}^{-1}$ of manure in the presence of NPK. In the absence of NPK, calculations indicated that respectively 23.0 and $22.9 \mathrm{tha}^{-1}$ of manure are needed to achieve the highest pod $\left(11.2 \mathrm{t} \mathrm{ha}^{-1}\right)$ and green grain $\left(9,9 \mathrm{t} \mathrm{ha}^{-1}\right)$ yields. The joint use of manure and NPK increased yields of pods and green grains in respectively 1.4 and $1.2 \mathrm{t} \mathrm{ha}^{-1}$ when compared to the use of only manure, which indicates that the use of both nutrient sources is the most adequate fertilization practice to Lima beans.

As for the dry grain yield, the use of $26.6 \mathrm{tha}^{-1}$ of manure in the presence of NPK allowed to reach the maximum value of $3.5 \mathrm{t} \mathrm{ha}^{-1}$ of dry grains (Figure 3 ), while in the absence of NPK, there were no significant effects of doses of manure. When no NPK was used, the average dry grain yield for all manure doses was $2.0 \mathrm{t} \mathrm{ha}^{-1}$. These results indicate that Lima beans can achieve good productivity levels in the edaphoclimatic conditions of Areia, with a potential similar to what was reported by Sirait et al. (1994) in US, $3.6 \mathrm{t} \mathrm{ha}^{-1}$, and by Vieira et al. (1992), $3.5 \mathrm{t} \mathrm{ha}^{-1}$, in the Brazilian State of Minas Gerais. When cattle manure was the only nutrient source, the average yield exceeded those obtained by Yuyama (1982), $1.0 \mathrm{t} \mathrm{ha}^{-1}$, and Santos et al. (2002), who reported a maximum of $0.85 \mathrm{tha}^{-1}$ of dry grains, using the same cultivar employed in the present work, with NPK fertilization.

When the present results are confronted to those of Santos et al. (2002), it is clear that the use of manure as the only nutrient source is also effective in increasing grain yield in Lima beans. This is a very relevant observation when small-scale farmers are taken into account, since organic amendments are often the only sources of fertilization they have at reach. Nevertheless, when mineral NPK was added, grain yield increased in $1.5 \mathrm{tha}^{-1}$, an indication that a balanced fertilization including both organic and mineral sources should be the recommendation for Lima beans nutrition, if the target is to improve yield standards.

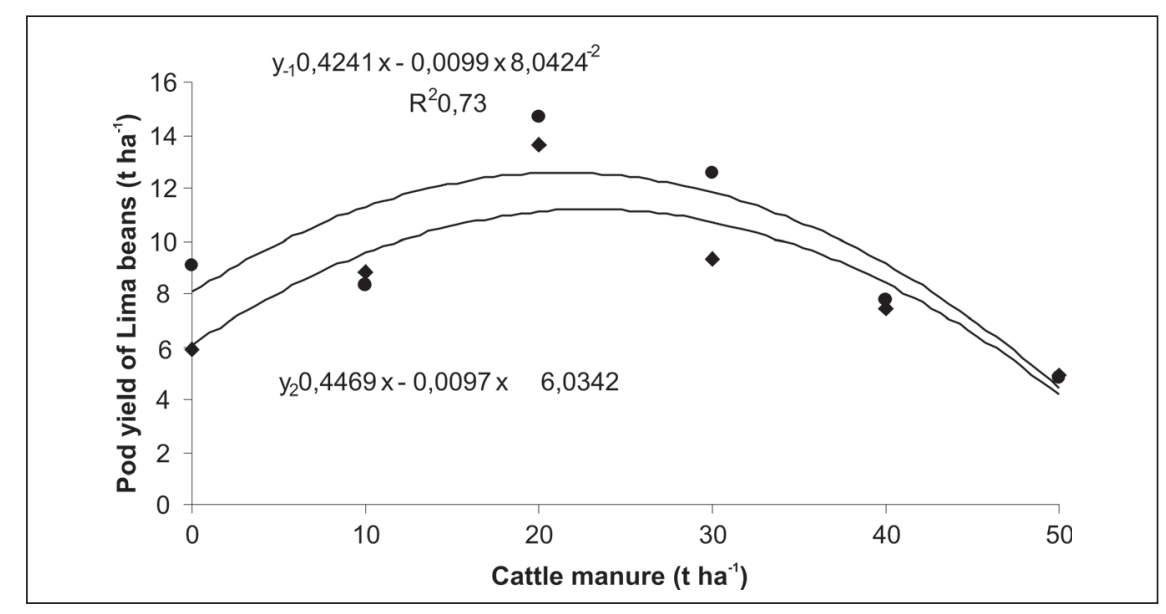

Figure 1. Pod yield of Lima beans, cultivar Raio-de-Sol, as function of cattle manure doses, in the presence $\left(\mathrm{y}_{1}\right)$ and absence $\left(\mathrm{y}_{2}\right)$ of NPK fertilization (produtividade de vagens de feijão-fava, cultivar Raio-de-Sol, em função de doses de esterco bovino, na presença $\left(\mathrm{y}_{1}\right)$ e ausência $\left(\mathrm{y}_{2}\right)$ de adubação NPK). Areia, UFPB, 2006.

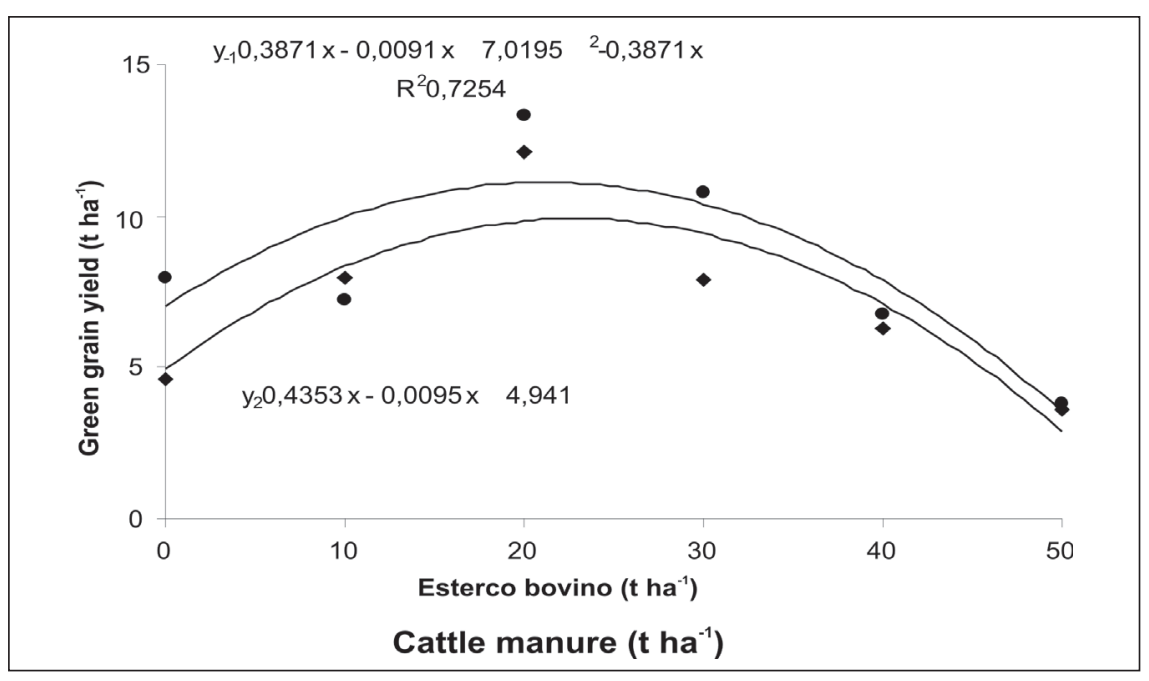

Figure 2. Green grain yield of Lima beans, cultivar Raio-de-Sol, as function of cattle manure doses, in the presence $\left(\mathrm{y}_{1}\right)$ and absence $\left(\mathrm{y}_{2}\right)$ of NPK fertilization (produtividade de grãos verdes de feijão-fava, cultivar Raio-de-Sol, em função de doses de esterco bovino, na presença $\left(\mathrm{y}_{1}\right)$ e ausência $\left(\mathrm{y}_{2}\right)$ de adubação NPK). Areia, UFPB, 2006.

The manure doses corresponding to the highest economic revenues for pod yield, in the presence and absence of NPK, as well as of dry grains in the presence of NPK, were determined by respectively the following equations: $(0.4241-0.086) /(2 \times 0.0099),(0.4469-$ $0.086) /(2 \times 0.0097)$, and $(0.2131-0.029) /$ (2x0.004). Therefore, the most economic doses were respectively 17.0 and $18.6 \mathrm{t} \mathrm{ha}^{-1}$ of manure to pod yield, respectively in the presence and absence of NPK, and $23.0 \mathrm{t} \mathrm{ha}^{-1}$ of manure, in the presence of NPK, for dry grain yield. The revenue due to the use of manure were estimated using the increments in pod yield (4.35 and $4.96 \mathrm{t} \mathrm{ha}^{-1}$, respectively in the presence and absence of NPK), and dry grains (2.78 $\mathrm{tha}^{-1}$, in the presence of NPK). When the cost of manure was deducted (17.0 $\mathrm{t} \mathrm{ha}^{-1}$ of manure $=1.47 \mathrm{t}$ of pods; $18.6 \mathrm{t} \mathrm{ha}^{-1}=$ $1.60 \mathrm{t}$ of pods; and $23.0 \mathrm{t} \mathrm{ha}^{-1}$ of manure $=0.66 \mathrm{t}$ of dry grains), the estimate net revenues were 2.88 and $3.36 \mathrm{tha}^{-1}$ of pods, respectively in the presence and absence of NPK, and $2.12 \mathrm{t} \mathrm{ha}^{-1}$ of dry grains, in the presence of NPK. The doses of highest economic efficiency represented 79 and $80 \%$ of the maximum pod yield, in the presence and absence of NPK, respectively, and 93\% 


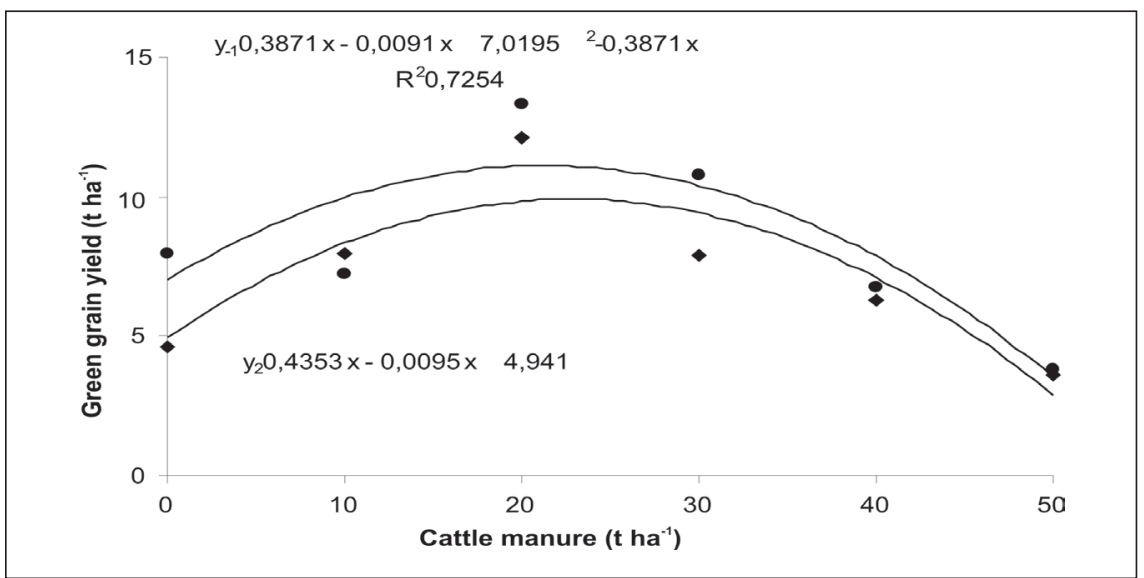

Figure 3. Dry grain yield of Lima beans, cultivar Raio-de-Sol, as function of cattle manure doses, in the presence of NPK fertilization (produtividade de grãos secos de feijão-fava, cultivar Raio-de-Sol, em função de doses de esterco bovino, na presença de adubação NPK). Areia, UFPB, 2006.

of the maximum dry grain yield. These results reveal the economic viability of using cattle manure in the fertilization of Lima beans, both in the presence and absence of NPK.

The benefit of manure on pod and green and dry grain yield, in the presence and absence of NPK, are likely to be a consequence of its high contents of $\mathrm{P}$ and $\mathrm{K}, 5.2$ and $4.9 \mathrm{~g} \mathrm{~kg}^{-1}$, respectively; but may come also from the improvement of the soil physical conditions caused by organic amendments. The increase in soil humidity and porosity (Asano, 1984) improve soil structure through the formation of humic-clay complexes, resulting in a rise on the $\mathrm{CEC}$ (Marchesini et al., 1988; Yamada \& Kamata, 1989). As consequence, there is a better use of the manure itself, and also of the NPK and soil-borne nutrients. Organic matter also favors the availability of $\mathrm{P}, \mathrm{K}$, and $\mathrm{Ca}$, and keeps $\mathrm{P}$ and other key nutrients in forms accessible to plants (Tibau, 1983).

\section{ACKNOWLEDGMENTS}

Authors thank CAPES for the scholarship granted to Adriana U Alves and also the Agriculture Agents Fran- cisco de Castro Azevedo, José Barbosa de Souza, Francisco Soares de Brito, and Francisco Silva do Nascimento, who make the field work happen.

\section{REFERENCES}

ARAÚJO JS; OLIVEIRA AP; SILVA JAL; RAMALHO CI; LUSTOSA NETO F. 2001. Rendimento de feijão-vagem cultivado com esterco suíno e adubação mineral. Revista Ceres 278: 501-510.

ASANO, J. 1984. Effect of organic manures on quality of vegetables. Japan Agricultural Research Quartely 18: 31-36.

BRASIL. Ministério da Agricultura. 1972. Levantamento exploratório-reconhecimento de solos do estado da Paraíba. Rio de Janeiro: MA - SUDENE. 669p. (Boletim Técnico, 15)

EMBRAPA. 1997. Manual de métodos de análise de solo. Rio de Janeiro: Serviço Nacional de Levantamento e Conservação de Solos. 212p.

EMBRAPA. 1999. Sistema Brasileiro de Classificação de Solos. Brasília: Embrapa Informação Tecnológica. 412 p.

FILGUEIRA FAR. 1981. Manual de olericultura. São Paulo: Ceres. 336p.

FILGUEIRA FAR. 2000. Novo manual de olericultura. Viçosa: UFV. 402 p.

FRAZÃO JEM; SANTOS D; FERREIRA FMB; OLIVEIRA FP; PEREIRA WE; SOUZA AP. 2004. Crescimento da fava em resposta a níveis de fósforo na presença e ausência de calagem em Latossolo Amarelo. In: FERTBIO, Anais... Lages: SBCS (CD-ROM).

HESTER JB; SHELTON FA; ISAACS JR. 1951. The rate and amount of plant nutrients absorved by various vegetables. Journal of the American Society for Horticultural Sciences 57: 249-251.
MARCHESINI A; ALLIEVI L; COMOTTI E; FERRARI A. 1988. Long-term effects of quality compost treatment on soil. Plant and Soil 106: 253-261.

NATALE W; COUTINHO ELM; BOARETTO A; PEREIRA FM. 1996. Dose mais econômica de adubo nitrogenado para a goiabeira em formação. Horticultura Brasileira 14: 196199.

OLIVEIRA AP; ALVES EU; ALVES AU; DORNELAS CSM; SILVA JA; PÔRTO ML; ALVES AU. 2004. Produção de feijão-fava em função do uso de doses de fósforo. Horticultura Brasileira 22: 543-546.

OLIVEIRA AP; ARAÚJO JS; ALVES EU; NORONHA MAS; CASSIMIRO CM; MENDONÇA FG. 2001. Rendimento de feijão-caupi cultivado com esterco bovino e adubo mineral. Horticultura Brasileira 19: 8184.

RAIJ BV. 1991. Fertilidade do solo e adubação. Piracicaba: Ceres. 343p.

SAEG. 2000. Sistema para análise estatística, versão 8.0. Viçosa: Fundação Arthur Bernardes.

SANTOS D; CORLETT FMF; MENDES JEMF; WANDERLEY JÚNIOR JSA. 2002. Produtividade e morfologia de vagens e sementes de variedades de fava no Estado da Paraíba. Pesquisa Agropecuária Brasileira 37: 1407-1412.

SILVA FN; MAIA SSS; OLIVEIRA M. 2000. Doses de matéria orgânica na produtividade da cultura da alface em solo eutrófico na região de Mossoró, RN. Horticultura Brasileira 18: 723-724. Suplemento.

TIBAU AO. 1983. Matéria orgânica e fertilidade do solo. São Paulo: Nobel. 220p.

UFC. 1990. Recomendações de adubação e calagem para o estado do Ceará. Fortaleza: Universidade Federal do Ceará. 247 p.

VIEIRA C. 1992a. Leguminosas de grãos: importância econômica na agricultura e na alimentação humana. Informe Agropecuário 16: 5-11.

VIEIRA RF. 1992b. A cultura do feijão-fava. Informe Agropecuário 16: 30-37.

VIEIRA RF; VIEIRA C; ANDRADE GA. 1992. Comparações agronômicas de feijões dos gêneros Vigna e Phaseolus com o feijãocomum (Phaseolus vulgaris L.). Pesquisa Agropecuária Brasileira 27: 841-850.

YAMADA H, KAMATA H. 1989. Agricultural technological evaluation of organic farming and gardening I. Effects of organic farming on yields of vegetables and soil physical and chemical properties. Horticultural Abstracts 59: 938-939.

YUYAMA K. 1982. Comportamento de 10 cultivares de feijão lima (Phaseolus lunatus L.) introduzidas do IITA, em terra firme de Manaus-AM. Acta Amazonica 12: 515-520. 